\title{
Oleaginous yeasts isolated from traditional fermented foods and beverages of Manipur and Mizoram, India, as a potent source of microbial lipids for biodiesel production
}

Pritam Bardhan', Kuldeep Gupta', Sumit Kishor², Pronobesh Chattopadhyay², Chayanika Chaliha', Eeshan Kalita', Vaibhav V. Goud ${ }^{3}$ and Manabendra Mandal ${ }^{1 *}$

\begin{abstract}
Purpose: Oleaginous yeasts can accumulate intracellular lipid bodies or triacylglycerides (TAGs) under nutrient limiting conditions. TAGs derived from those yeast strains are considered as an alternative to conventional plantbased oils for biodiesel production. In this study, we attempt to isolate and characterize yeast strains from selected traditional fermented foods of Manipur and Mizoram, India, and study their oleaginous attributes for biodiesel production.

Method: Fourteen potential oleaginous yeasts were isolated from fermented food samples of Manipur and Mizoram, India. The isolates were identified by 5.8S internal transcribed spacer (ITS) rRNA gene sequencing. Intracellular TAG accumulation by yeast cells were confirmed by Nile red fluorescence microscopy and spectrometry technique. The most promising isolates were evaluated for lipid accumulation having different initial carbon to nitrogen $(C / N)$ ratios and also the full kinetic studies (depicting the glucose consumption, biomass, and lipid production) using optimum C/N ratio were estimated. Fatty acid methyl esters (FAME) profile of the transesterified lipids were analyzed by GC-MS.

Results: The identified yeast isolates belonged to seven different genera viz. Rhodotorula, Pichia, Candida, Saturnispora, Wickerhamomyces, Zygoascus, and Saccharomyces. Under nitrogen-limiting conditions, maximum biomass concentration of $5.66 \pm 0.03 \mathrm{~g} / \mathrm{L}$ and $4.713 \pm 0.03 \mathrm{~g} / \mathrm{L}$ was produced by Wickerhamomyces anomalus FK09 and Pichia kudriavzevii FK02, respectively. The highest lipid concentration (g lipid/L fermentation broth) of $0.58 \mathrm{~g} / \mathrm{L}$ was attained by Rhodotorula mucilaginosa R2, followed by Wickerhamomyces anomalus FK09 $(0.51 \mathrm{~g} / \mathrm{L})$, and Zygoascus hellenicus FC10 (0.41 g/L). Rhodotorula mucilaginosa R2 exhibited the maximum lipid content (\% lipid $/ \mathrm{g}$ dry cell weight) of $(21.63 \pm 0.1 \%)$ after $96 \mathrm{~h}$ of growth. The $\mathrm{C} / \mathrm{N}$ ratio of 40 and 20 was found to be optimum for $R$. mucilaginosa R2 and W. anomalus FK09 with a lipid content of $22.21 \pm 0.4 \%$ and $12.83 \pm 0.08 \%$ respectively.

Conclusion: Newly isolated yeast strains were obtained from traditional fermented food samples of Manipur and Mizoram, India. FAME analysis of the transesterified lipid extracts suggested the potential use of yeast-derived oil as an alternative to vegetable oil for biodiesel production.
\end{abstract}

Keywords: Oleaginous yeast, Triacylglycerides, Fermented food, Rhodotorula mucilaginosa R2

\footnotetext{
* Correspondence: mandal@tezu.ernet.in; manavigib@yahoo.co.in

'Department of Molecular Biology and Biotechnology, Tezpur University,

Tezpur, Assam 784028, India

Full list of author information is available at the end of the article
}

(c) The Author(s). 2020 Open Access This article is licensed under a Creative Commons Attribution 4.0 International License, which permits use, sharing, adaptation, distribution and reproduction in any medium or format, as long as you give appropriate credit to the original author(s) and the source, provide a link to the Creative Commons licence, and indicate if changes were made. The images or other third party material in this article are included in the article's Creative Commons licence, unless indicated otherwise in a credit line to the material. If material is not included in the article's Creative Commons licence and your intended use is not permitted by statutory regulation or exceeds the permitted use, you will need to obtain permission directly from the copyright holder. To view a copy of this licence, visit http://creativecommons.org/licenses/by/4.0/. 


\section{Introduction}

Plant-based oils are the primary source for the conventional production of biodiesel and act as a substitute to the depleting fossil fuel reserves (Sitepu et al. 2014). However, huge land area requirement for crop cultivation (both edible and non-food crops) and issues over food security have led researchers to explore alternatives to sustain the biodiesel industry (Ma et al. 2018). Oleaginous yeasts store above 20\% of their dry cell weight as intracellular triacylglycerols. These yeasts are considered as cell factories amenable for the commercial production of biodiesel, polyunsaturated fatty acids, and exotic fats like cocoa butter (Bellou et al. 2016, Papanikolaou and Aggelis 2019). Oleaginous yeasts predominantly belong to the genera Rhodosporidium, Cryptococcus, Rhodotorula, Yarrowia, Lipomyces, and Trichosporon (Zhu et al. 2008; Abghari and Chen 2014; Zhang et al. 2016; Deeba et al. 2017; Khot and Ghosh 2017; Blomqvist et al. 2018). Yeasts are well-suited for commercial production of microbial lipids over other oleaginous microorganisms like algae and filamentous fungi because of its ability to reach high cell densities in a short time (Sitepu et al. 2014), having similar composition of fatty acid as those of plant-based oils (Deeba et al. 2016) and capability of producing a variety of metabolic co-products including high-value carotenoids, proteins and polysaccharide rich streams of deoiled biomass, and various organic acids (Bellou et al. 2014; Kot and Kurcz 2016; Parsons et al. 2020). Furthermore, several researchers have highlighted the use of microbial lipids as a source of renewable oleochemicals like surfactants, cosmetics, lubricants, textiles, paints, plastics, and soaps (Steen et al. 2010; Zhou et al. 2016). Nutrient limitation, particularly, high $\mathrm{C} / \mathrm{N}$ ratio in the growth medium has been reported to induce lipogenesis (Ratledge 2002). During such stress conditions, oleaginous yeasts accumulate high amounts of triacylglycerol in the form of intracellular lipid bodies (LBs) (Poontawee et al. 2018; Bardhan et al. 2019a). However, out of the 1600 described yeast species, only 70 are known to store lipids above $20 \%$ of their cell dry weight (Sitepu et al. 2014; Patel et al. 2019). Therefore, screening studies are crucial for the discovery of new oleaginous yeast species (Schulze et al. 2014; Lamers et al. 2016). Recent screening and molecular characterization studies have led to the identification of some novel oleaginous yeast strains which include Cystobasidium oligophagum JRC1 (Vyas and Chhabra 2017), Meyerozyma guilliermondii BI281A (Ramírez-Castrillón et al. 2017), and Cystobasidium iriomotense (Tanimura et al. 2018) as the potential feedstock for biodiesel production.

Oleaginous yeasts have been isolated from several fermented foods including Kefir (fermented milk product) and other dairy products like cheese, milk, and yoghurt (Jiru et al. 2016; Gientka et al. 2017). North-East Indian states have diverse ethnic backgrounds and fermented foods like soya bean, bamboo shoot, and fermented alcoholic and non-alcoholic beverages are consumed regularly by the local people (Das et al. 2016). In this study, we attempt to isolate and characterize yeast strains from some selected traditional fermented foods and beverages of Manipur and Mizoram, India, and study their ability to accumulate lipids under nitrogen-limiting conditions using glucose as a carbon source. The most promising isolates R2 and FK09 (selected on the basis of highest biomass and lipid content) were evaluated for lipid accumulation having different initial carbon to nitrogen $(\mathrm{C} /$ $\mathrm{N})$ ratios and also the full kinetic studies (depicting the glucose consumption, biomass, and lipid production) using optimum $\mathrm{C} / \mathrm{N}$ ratio were estimated. The fatty acid composition of the transesterified lipid extracts derived from the yeast strains were analyzed and compared with plant-based oils. This is the first report on the isolation of oleaginous yeasts from the fermented foods of India for lipid production and hence these strains could be used in future as a potential source of microbial lipids for biodiesel production.

\section{Materials and methods}

\section{Chemicals and media}

All the microbiological media supplements, general chemicals, and reagents like agar, malt extract, peptone, Nile red, $\mathrm{BF}_{3}$-methanol reagent, and streptomycin were procured from HiMedia, India. Standard FAME Mix C14-22 was procured from Sigma-Aldrich, India, and analytical grade solvents like chloroform, methanol, and $\mathrm{n}$-hexane were purchased from Merck Ltd., India.

\section{Isolation of yeast strains from traditional fermented foods of Manipur and Mizoram, India}

A total of ten different fermented foods were procured from the local markets of Imphal (Manipur, India) and Aizawl (Mizoram, India). These included fermented bamboo shoots (Soidon, soibum), fermented fish (Ngari), fermented fish pate (Hentek), and fermented soya beans (Hawaijar), which were collected from Manipur. The traditional fermented food from Mizoram included fermented banana flower, fermented soya beans, fermented pig fat, and fermented beverages like orange juice (hathkhora thoi) and lemon juice. Yeast extract peptone dextrose (YEPD) agar medium containing $(\mathrm{g} / \mathrm{L})$ yeast extract, 3 ; peptone, 5 ; dextrose, 10; malt extract, 3; and agar, 18 (pH 6.8) amended with $100 \mu \mathrm{g} / \mathrm{ml}$ of filter sterilized streptomycin was used for the selective isolation of yeast strains. The homogenate was prepared by mixing $10 \mathrm{~g}$ of the sample in $90 \mathrm{ml} 0.87 \%(\mathrm{w} /$ v) physiological saline and kept in an orbital shaker at 28 ${ }^{\circ} \mathrm{C}, 120 \mathrm{rpm}$ for $30 \mathrm{~min}$. One milliliter of this mixture was used for the isolation of yeast strains by spreading $100 \mu \mathrm{l}$ of diluted sample on YEPD agar plates, which were incubated at $28^{\circ} \mathrm{C}$ for $72-96 \mathrm{~h}$. 


\section{Identification of the yeast strains}

Fungal genomic DNA Purification Kit (HiMedia, India) was used to extract and purify the genomic DNA of all the yeast isolates according to the manufacturer's protocol. Primer set ITS-1(5'-TCCGTAGGTGAACCTGCGG-3') and ITS4 (5'-TCCTCCGCTTATTGATATGC-3') was used to amplify the $5.8 \mathrm{~S}$ internal transcribed spacer (ITS) region of the rRNA gene using polymerase chain reaction (PCR) (White et al. 1990). Primer set NL-1 (5'-GCATATCAAT AAGCGGAGGAAAAG-3') and NL-4 (5'-GGTCCG TGTTTCAAGACGG-3') was used to amplify the D1/D2 domain of the 26S rRNA gene (Saikia et al. 2018). A total reaction mixture of $50 \mu \mathrm{l}$ comprising of Dream Taq PCR 2 $\times$ master-mix, $25 \mu \mathrm{l}$ (Thermo Scientific); nuclease free water, $19 \mu \mathrm{l} ; 10 \mu \mathrm{M}$ of forward and reverse primers, $2 \mu \mathrm{l}$ each; and template DNA (40-90 ng/ $\mu \mathrm{l}), 2 \mu \mathrm{l}$, was constituted for PCR. The reaction was performed in a thermal cycler (Eppendorf) using a method described elsewhere with slight modifications (Manhar et al. 2015). The amplification parameters were as follows: initial denaturation $\left(95{ }^{\circ} \mathrm{C}, 2\right.$ min), followed by 36 cycles of denaturation $\left(94{ }^{\circ} \mathrm{C}, 1 \mathrm{~min}\right)$, annealing $\left(54{ }^{\circ} \mathrm{C}, 30 \mathrm{~s}\right)$, elongation $\left(72{ }^{\circ} \mathrm{C}, 1 \mathrm{~min}\right)$, and final elongation $\left(72{ }^{\circ} \mathrm{C}, 10 \mathrm{~min}\right)$ and then subsequently cooled at $4{ }^{\circ} \mathrm{C}$. PCR products were separated in $2 \%(\mathrm{w} / \mathrm{v})$ agarose gel (Sigma) in $1 \times$ Tris-acetate-EDTA buffer (pH 8.3). A 100 bp DNA ladder (Thermo Fisher Scientific) was used to ascertain the size of the obtained PCR products. Amplicons (size ranging from 355 to 790) were sequenced by the 1st BASE DNA sequencing service (Selangor, Malaysia). DNA sequences were analyzed with NCBI-BLAST (https://blast. ncbi.nlm.nih.gov). The phylogenetic tree was constructed using neighbor-joining method by CLC sequence viewer 7.6.1. Confidence levels of the clades were determined from bootstrap test (1000 replicates) as depicted on the nodes of the branches.

\section{Growth of the yeast strains on lipid production media}

Yeast strains were cultivated by introducing a loop of one colony from YEPD agar onto $50 \mathrm{ml}$ YEPD broth and incubated at $28{ }^{\circ} \mathrm{C}, 140 \mathrm{rpm}$. One milliliter of log phase culture (O.D was adjusted by phosphate buffer saline, $\mathrm{pH} \mathrm{7,} \mathrm{corresponding} \mathrm{to} \mathrm{approximately} 10^{7}$ cells $/ \mathrm{ml}$ ) was inoculated into $100 \mathrm{ml}$ of lipid production medium comprising of $(\mathrm{g} / \mathrm{L})$, glucose, 30 ; yeast extract, $1.5 ; \mathrm{NH}_{4} \mathrm{Cl}$, $0.5 ; \mathrm{Na}_{2} \mathrm{HPO}_{4} .12 \mathrm{H}_{2} \mathrm{O}, 5 ; \mathrm{KH}_{2} \mathrm{PO}_{4}, 7 ; \mathrm{CaCl}_{2} .2 \mathrm{H}_{2} \mathrm{O}, 0.1$; $\mathrm{MgSO}_{4} .7 \mathrm{H}_{2} \mathrm{O}, 1.5 ; \mathrm{FeCl}_{3} .6 \mathrm{H}_{2} \mathrm{O}, 0.08 ; \mathrm{ZnSO}_{4} .7 \mathrm{H}_{2} \mathrm{O}, 0.01$; $\mathrm{CuSO}_{4} .5 \mathrm{H}_{2} \mathrm{O}, 0.1$ and in $(\mathrm{mg} / \mathrm{L}), \mathrm{MnSO}_{4} .5 \mathrm{H}_{2} \mathrm{O}, 0.1$; $\mathrm{Co}\left[\mathrm{NO}_{3}\right]_{2} \cdot 6 \mathrm{H}_{2} \mathrm{O}, 0.1$ and $\mathrm{pH}$ was adjusted to 5.5. The flasks were incubated at $28{ }^{\circ} \mathrm{C}, 140 \mathrm{rpm}$ for $96 \mathrm{~h}$ in an orbital shaker (Orbitek, Scigenics Biotech). Glucose in excess $(30 \mathrm{~g} / \mathrm{L})$ was used as a carbon source and a limited concentration of $0.5 \mathrm{~g} / \mathrm{L} \mathrm{NH}_{4} \mathrm{Cl}$ along with yeast extract ( $\mathrm{N}$ total $11 \%$ ) was used as the only nitrogen source $(\mathrm{C} / \mathrm{N}$ molar ratio 17.81$)$ in the culture medium. $\mathrm{C} / \mathrm{N}$ ratio was calculated as the ratio of moles of carbon (glucose) to the moles of nitrogen (ammonium chloride). Different amount of ammonium chloride was added to control the $\mathrm{C} / \mathrm{N}$ ratio. Further, intracellular lipid accumulation by yeast isolates growing on lipid production medium was confirmed using the Nile red staining followed by fluorescence microscopy and spectrometry.

\section{Analysis of biomass yield, total extracted lipids, and glucose}

The yeast dry weight was estimated gravimetrically; 10 $\mathrm{ml}$ culture broth was centrifuged at $7500 \mathrm{rpm}$ for 10 min. The pellet containing the wet cell mass was washed thrice with sterile distilled water, and kept for drying at $65{ }^{\circ} \mathrm{C}$. Total lipids were extracted by the method of (Bligh and Dyer 1959) with slight modification. One hundred milligrams of the dried biomass was briefly treated with $1.32 \mathrm{ml}$ of $4 \mathrm{M} \mathrm{HCL}$ and kept in a water bath at $75{ }^{\circ} \mathrm{C}$ for $1 \mathrm{~h}$. To the acid hydrolyzed biomass, methanol, chloroform, and water were added sequentially in the ratio of 2:2:1.8 (v/v/v) and vortexed for 2 min after each solvent addition. The chloroform layer containing the total extracted lipids was obtained by centrifugation at $6500 \mathrm{rpm}$ for $10 \mathrm{~min}$ and collected in a pre-weighed vial. The collected chloroform layers were kept in an oven $\left(65^{\circ} \mathrm{C}\right)$ for drying until constant dry weight and the final weight of the vial was recorded. The parameters for lipid production were determined according to (Uprety et al. 2017). Residual sugar in the media was estimated by dinitrosalicylic acid (DNSA) method (Miller, 1959) using glucose as a standard.

\section{Detection of intracellular LBs by Nile red staining and fluorescence microscopy}

The intracellular lipid bodies (LBs) suggestive of lipid accumulation inside the yeast cells were detected and analyzed by the method of (Bardhan et al. 2019b). Briefly, 10 $\mu \mathrm{l}$ of Nile red solution $(0.1 \mathrm{mg} / \mathrm{ml}$ in DMSO) was added to $40 \mu \mathrm{l}$ of the culture broth. The mixture was incubated at room temperature for 5 min in dark. A fluorescence microscope (Olympus BX43) was used to observe the yeast cells under $\times 100$ objective lens $(450-490 \mathrm{~nm}$ excitation filter, $505 \mathrm{~nm}$ diachronic mirror) which allowed visualizing the stained lipid bodies (yellow-gold fluorescence). Those yeast cells having many and/or large lipid bodies were selected for quantitative analysis of neutral lipids accumulation by fluorescence spectrometry.

\section{Quantification of the accumulated neutral lipid by fluorescence spectrometry}

The fluorescence spectrometry experiment was performed as reported by (Kimura et al. 2004) with slight modifications. Two milliliters of phosphate buffer saline (pH 7.0) was added to $100 \mu \mathrm{l}$ of the culture broth was 
and mixed well. Seven hundred microliters of the cell suspension without Nile red was taken in a cuvette and the spectrum was recorded in the visual wavelength range (400-700 nm) using a fluorescence spectrometer (LS55, Perkin Elmer) with PC control equipment. The excitation was fixed at $488 \mathrm{~nm}$. Ten microliters of Nile red was then added to the diluted culture broth and incubated for $5 \mathrm{~min}$ in dark. The cell suspension was mixed well and the spectrum was recorded again in the same wavelength range. PC control equipment was used to correct the spectra (by subtracting the emission spectra obtained before and after Nile red addition). The amount of intracellular lipids accumulated in the yeast cells corresponds to the fluorescence intensity (units) at the peak of the spectrum.

\section{Transesterification of yeast derived lipids and GC-MS analysis}

The transesterification reaction of the obtained lipids was performed according to (Morrison and Smith 1964). One milliliter of $\mathrm{BF}_{3}$-methanolic reagent was added to $10 \mathrm{mg}$ of lipid extract and the mixture was incubated at $80{ }^{\circ} \mathrm{C}$ for $30 \mathrm{~min}$. A mixture of hexane and water in the ratio of 2:1 (v/v) was used to extract the methyl esters followed by centrifugation at $6500 \mathrm{rpm}$ for $5 \mathrm{~min}$. The upper hexane layer was analyzed by gas chromatographymass spectrometry (GC 7890B, MS5977A) equipped with flame ionization detector (FID) and HP-5MS capillary column (Agilent, USA). One microliter of the sample was injected in split less mode $\left(250{ }^{\circ} \mathrm{C}\right.$, carrier gas: helium, flow rate: $1 \mathrm{ml} / \mathrm{min}$ ). Column temperature was initially set at $50{ }^{\circ} \mathrm{C}$ and raised to $180{ }^{\circ} \mathrm{C}$ at a gradient of $25{ }^{\circ} \mathrm{C} / \mathrm{min}$. Subsequently, it was further raised to $220^{\circ} \mathrm{C}$ at a gradient of $10{ }^{\circ} \mathrm{C} / \mathrm{min}$ and held for $1 \mathrm{~min}$. Finally, the temperature was ramped at $250{ }^{\circ} \mathrm{C}$ at a gradient of $15{ }^{\circ} \mathrm{C} / \mathrm{min}$ (Deeba et al. 2016). The retention times and mass spectra of the obtained FAMEs were identified using standard FAME mix, C14-22 (Sigma Aldrich).

\section{Statistical analysis}

The data were obtained from three independent experiments and represented as mean values with standard error using Excel 2010 Program. The statistical program SPSS version 16 was used for statistical analysis. Oneway ANOVA was employed to study the differences in lipid production parameters among yeast strains. For comparison of the means, the Duncan's multiple range tests $(p<0.05)$ were used.

\section{Results and discussion}

\section{Identification of yeast strains isolated from selected} fermented foods of Manipur and Mizoram

Seventeen yeast isolates were established as pure culture from traditional fermented food and beverages of Manipur and Mizoram, India (Fig. 1 depicts the colony morphology of some of the representative yeast isolates growing on YEPD agar medium). Amplification of 5.8S-ITS region of the rRNA gene resulted in amplicons with size ranging from 355 to 790 base pairs (Fig. 2). Amplicons corresponding to isolates FO05, FO08, and FC11 were sequenced and found to be the same organism (all showing $100 \%$ sequence similarity with Saturnispora diversa (KY105317.1)), so only isolate FO05 was taking into account. Similarly, isolate FK01 and R6 were sequenced and found to be $100 \%$ similar to Rhodotorula mucilaginosa culture CBS: 7014 (KY104857.1) and therefore only FK01 was considered in our study. The nucleotide sequences were deposited to NCBI GenBank and the accession numbers were generated as shown in Table 1. Yeast isolates belonging to seven different genera viz. Pichia, Saccharomyces, Saturnispora, Candida, Wickerhamomyces, Zygoascus, and Rhodotorula were identified. Figure 3 depicts the phylogenetic relationship of all the obtained yeast isolates. Based on 5.8S ITS rRNA gene analysis, 8 yeast strains were identified to belong to the phylum Ascomycota and 6 strains representing the Rhodotorula genera were placed in the phylum Basidiomycota. Molecular typing of yeast isolates by using ITS1 and ITS4 primers for identifying the 5.8S-ITS region of rRNA gene and NL1 and NL4 primers for the identification of D1/D2 region of $26 \mathrm{~S}$ rRNA gene were depicted in Fig. 4. The identification of the 5.8S-ITS rDNA region is considered to exhibit the highest resolving power for discriminating closely related fungal species (Schoch et al. 2012; Filippousi et al. 2019). Oleaginous yeasts belonging to genera Candida, Debaryomyces, Kluyveromyces, Kazachstania, and Zygotorulaspora were also identified (based on 5.8S ITS rDNA sequence similarities) from the kefir grains (Gientka et al. 2017). In another study (Jiru et al. 2016), 18 oleaginous yeasts were identified according to gene sequences of ITS region of 5.8S rRNA gene and D1/D2 domain of the 26S rRNA gene. The diversity of yeast strains obtained in our study has been compared with the other reported studies concerning yeast diversity from food samples including several traditional fermented foods like sourdough, kefir grains, and other fermented condiments and milk products; surface and the body of red and white grapes, apples, prickly pears, damsons etc., from olive brine and vinegar were isolated and screened towards their ability to produce organic acids, polyols, and microbial lipids as shown in (Table 2).

Biomass yield and lipid content of different yeast isolates The relative lipid production parameters (biomass concentration, lipid content, and lipid concentration) of the isolated yeast strains are shown in Table 3. Among all the tested yeast strains, significantly high biomass concentration of $4.7 \pm 0.03^{\mathrm{g}} \mathrm{g} / \mathrm{L}$ and $5.6 \pm 0.03^{\mathrm{h}} \mathrm{g} / \mathrm{L}$ was 


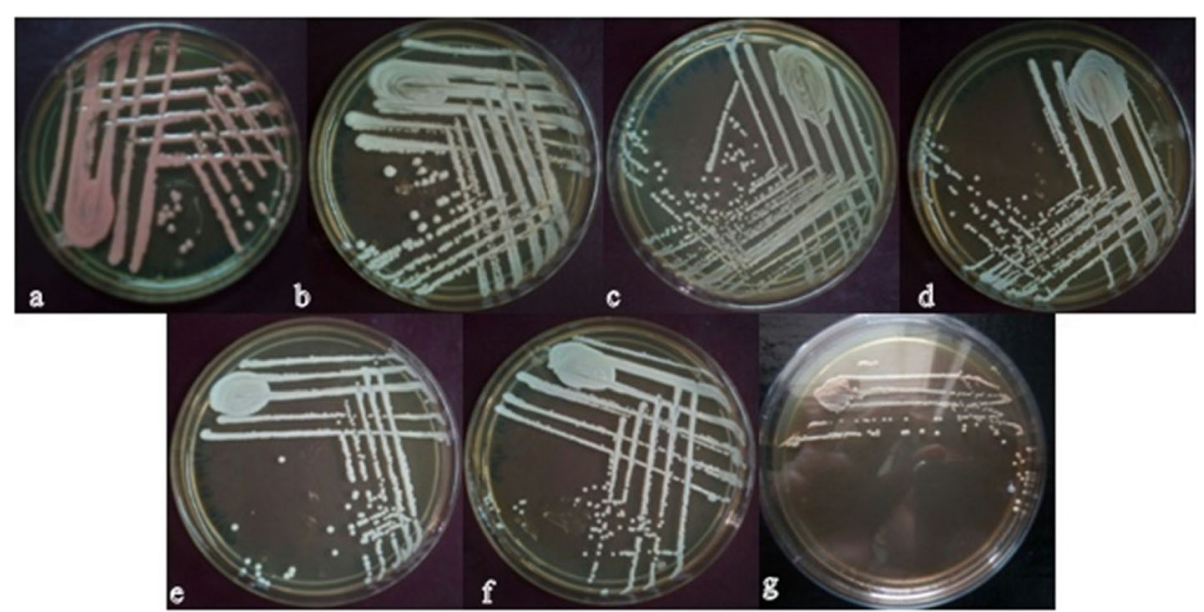

Fig. 1 Colony morphology of yeast isolates growing on YEPD agar medium (representing one from each genera): a Isolate R2, b Isolate FK03, c Isolate FK04, d Isolate FO05, e Isolate FKO9, f Isolate FC10, g Isolate YMA1

obtained with Pichia kudriavzevii FK02 and Wickerhamomyces anomalus FK09 and in terms of lipid concentration; $0.41^{\mathrm{ef}} \mathrm{g} / \mathrm{L}, 0.44^{\mathrm{f}} \mathrm{g} / \mathrm{L}, 0.51^{\mathrm{g}} \mathrm{g} / \mathrm{L}$, and $0.58^{\mathrm{h}} \mathrm{g} / \mathrm{L}$ was obtained with Zygoascus hellenicus FC10, Rhodotorula mucilaginosa R4, Wickerhamomyces anomalus FK09, and Rhodotorula mucilaginosa R2, respectively. Average lipid content of yeasts has been reported to be in the range of 5 to $15 \%$ of total dry weight (TDW) (Phukan et al. 2019). However, much higher lipid content ranging from (22.1 to $68 \%$ ) has been obtained with oleaginous yeasts using hydrophilic carbon sources like glucose, glycerol, and different biomass hydrolysates under various cultivation conditions (Athenaki et al. 2018). In this study, $R$. mucilaginosa $\mathrm{R} 2$ exhibited the maximum lipid content $\left(21.63 \pm 0.1^{\mathrm{i}} \%\right)$ after $96 \mathrm{~h}$ of growth in glucosebased lipid production medium. The lipid content of Rhodotorula mucilaginosa strains, isolated from various samples including dairy products, varied in the range of $19.67 \pm 0.28$ to $38.61 \pm 0.39 \%$ (Jiru et al. 2016). The biomass and lipid content of some of the yeast strains obtained in this study has been compared with other reported oleaginous yeasts as shown in (Table 4). Saturnispora diversa FO05 and Zygoascus hellenicus FC10 were isolated from traditional fermented beverage, hathkhora thoi of Mizoram. S. diversa FO05 was found to be slow growing yeast with the least biomass production $\left(2.09 \pm 0.05^{\mathrm{a}} \mathrm{g} / \mathrm{L}\right)$ among all the isolated yeast strains. However, the lipid concentration in S. diversa FO05 was found to be $0.39^{\mathrm{de}} \mathrm{g} / \mathrm{L}$ with a lipid output of $18.57 \pm$ $0.6^{\mathrm{h}} \%$. S. diversa belongs to the phylum Ascomycota, which was recently transferred from Candida diversa (Kurtzman 2015). To the best of our knowledge, there are no reports on microbial lipid production by $S$. diversa and $Z$. hellenicus. However, S. diversa and $Z$.

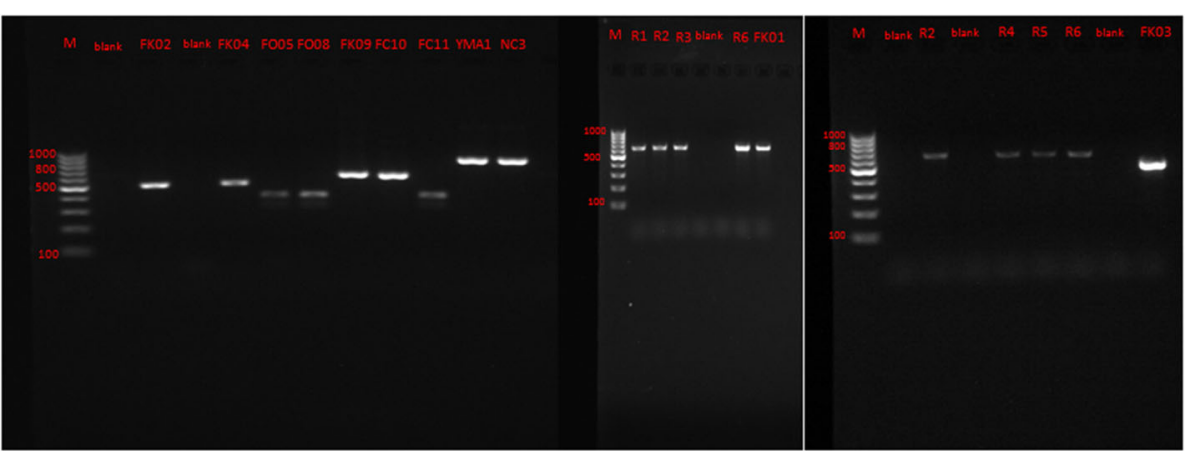

Fig. 2 Electrophoretic separation of PCR amplification products on 2\% agarose gel (M-100 bp DNA ladder, FK02-Pichia kudriavzevii isolate FK02, FK04-Candida parapsilosis isolate FK04, FO05-Saturnispora diversa isolate FO05, FO08-Saturnispora diversa isolate FO08, FK09-Wickerhamomyces anomalus isolate FK09, FC10-Zygoascus hellenicus isolate FC10, FC11-Saturnispora diversa isolate FC11, YMA1-Saccharomyces cerevisiae isolate YMA1, NC3-Saccharomyces cerevisiae isolate NC3, R1-Rhodotorula mucilaginosa isolate R1, R2-R. mucilaginosa isolate R2, R3-R. mucilaginosa isolate R3, R4-R. mucilaginosa isolate R4, R5-R. mucilaginosa isolate R5, R6-R. mucilaginosa isolate R6, FK01-R. mucilaginosa isolate FK01, FK03-Pichia kudriavzevii isolate FK03) 
Table 1 Sequence analysis of 5.8S-ITS region of rRNA gene of the isolates

\begin{tabular}{lllllll}
\hline & & & & \\
SL no. & Isolate no. & Size of PCR product (bp) & Homology (\%) & Closest-related species & GeneBank accession no. \\
\cline { 2 - 5 } 1 & FK02 & 481 & 99 & Pichia kudriavzevii strain BSFL-3 (KY457575.1) & MH299860 \\
2 & FK04 & 477 & 100 & Candida parapsilosis strain h56b (KP674744.1) & MH299862 \\
3 & FO05 & 355 & 99 & Saturnispora diversa (KY105317.1) & MH299863 \\
4 & FK09 & 572 & 100 & Wickerhamomyces anomalus (KT175180.1) & MH299864 \\
5 & FC10 & 563 & 99 & Zygoascus hellenicus (AY447032.1) & MH299865 \\
6 & YMA1 & 790 & 100 & Saccharomyces cerevisiae strain TU9 (KU535590.1) & MH299866 \\
7 & NC3 & 787 & 100 & Saccharomyces cerevisiae YJM1592 (CP006433.1) & MH299867 \\
8 & R1 & 568 & 100 & Rhodotorula mucilaginosa isolate2 (MG020687.1) & MH299854 \\
9 & R2 & 527 & 100 & R. mucilaginosa strain S05 (KX866274.1) & MH299855 \\
10 & R3 & 518 & 100 & R. mucilaginosa strain RH2 (MG969795.1) & MH299856 \\
11 & R4 & 571 & 100 & R. mucilaginosa strain SBM-IAUF-2 (MG711888.1) & MH299857 \\
12 & R5 & 572 & 100 & R. mucilaginosa strain AUMC 11221 (KY611824.1) & MH299858 \\
13 & FK01 & 569 & 99 & R. mucilaginosa culture CBS:7014 (KY104857.1) & MH299859 \\
14 & FK03 & 459 & 100 & Pichia kudriavzevii strain YB-25 (MF062195.1) & MH299861 \\
\hline
\end{tabular}

hellenicus have been reported to produce ethanol from various monosaccharides (Kodama et al. 2013; Jaiboon et al. 2016). Similarly, S. cerevisiae strains YMA1 and NC3 should produce ethanol on glucose-based medium despite aerobic conditions that were imposed ("Crabtree"-positive yeasts) and therefore accumulate lower quantities of reserve lipids (De Deken, 1966; Sitepu et al. 2014).

The $\mathrm{C} / \mathrm{N}$ molar ratio initially used for screening of yeast strains for lipid accumulation (Table 4) was 17.81. Two strains $W$. anomalus FK09 and R. mucilaginosa R2 (selected on the basis of highest biomass and lipid content respectively) were tested for lipid accumulation using glucose-based medium having different $\mathrm{C} / \mathrm{N}$ molar ratios $(20,40,60,80$, and 100$)$ and also a full kinetic studies (depicting the glucose consumption, total dry weight, and lipid concentration) using optimum $\mathrm{C} / \mathrm{N}$ ratio were estimated (Fig. 5). The $\mathrm{C} / \mathrm{N}$ ratio of 40 and 20 was found to be optimum for $R$. mucilaginosa R2 and $W$. anomalus FK09 with a lipid content of $20.67 \%$ and
$12.82 \%$ respectively. In case of $R$. mucilaginosa $\mathrm{R} 2$, the lipid content increased significantly from $7.08 \pm 0.1^{\mathrm{a}}$ to $20.67^{\mathrm{d}} \%$ when the $\mathrm{C} / \mathrm{N}$ molar ratio was increased from 20 to 40 . Further increasing the $\mathrm{C} / \mathrm{N}$ ratio (from 40 to 100) lowered the lipid yield. This could be attributed to the fact that high glucose concentration results in a high osmotic pressure and also the sharp decrease in $\mathrm{pH}$ due to excessive glucose consumption as confirmed by recording the $\mathrm{pH}$ of the culture medium after fermentation ( $\mathrm{pH}$ 3.51) ( $\mathrm{Zhu}$ et al. 2008). Lower the biomass yield, higher is the lipid content in the cells (Kolouchova et al. 2016). At $\mathrm{C} / \mathrm{N}$ ratio of 100 , the lipid content significantly decreased with increased biomass yield. Similar results were obtained by Zhu et al. (2008) but at a much higher $\mathrm{C} / \mathrm{N}$ ratio above 140 . Filippousi et al. (2019) reported non-negligible production of cellular lipids (16.9 to $29.9 \%$ of TDW) by Yarrowia lipolytica and Debaromyces strains under nitrogen-limiting condition using glycerol-based carbon source and also a

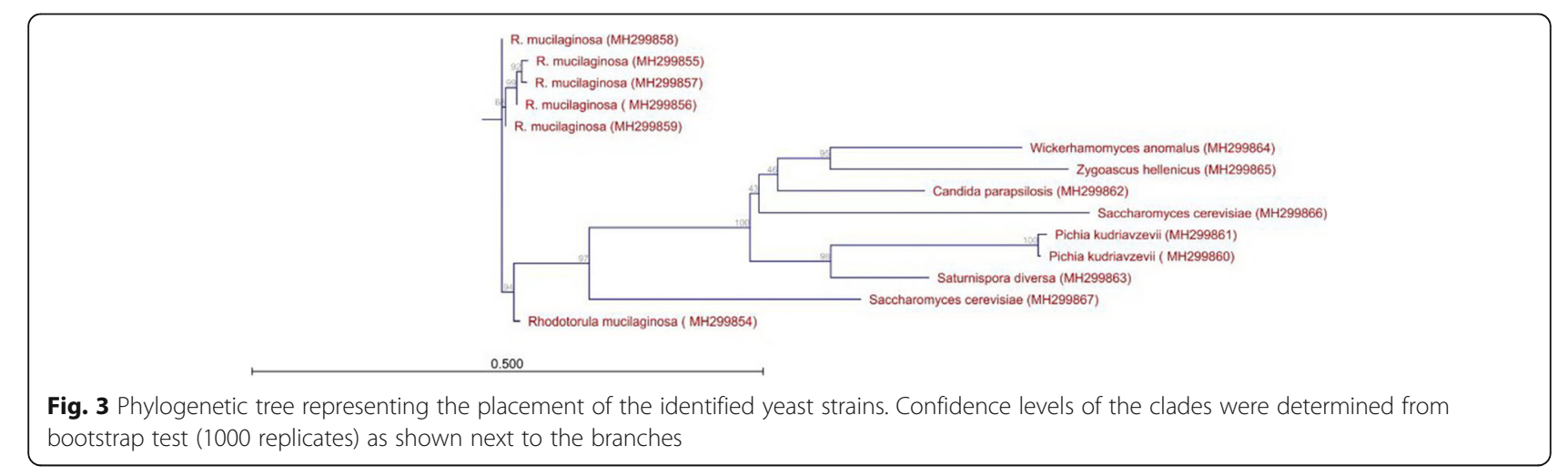




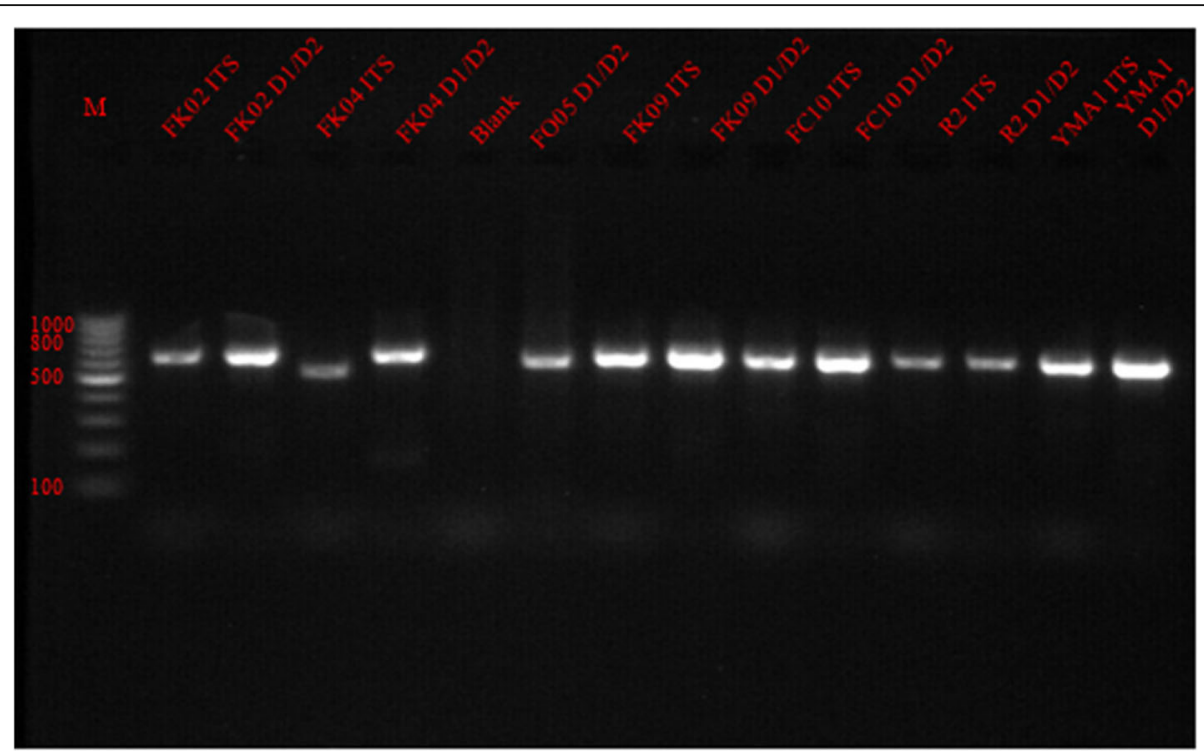

Fig. 4 Molecular typing of yeast isolates by using $5.8 \mathrm{~S}$ ITS (internal transcribed spacer)-primer and 26S rRNA gene D1/D2 region-primer, Mmolecular marker (100 bp DNA ladder), FK02-Pichia kudriavzevii, FK04-Candida parapsilosis, FO05-Saturnispora diversa, FK09-Wickerhamomyces anomalus, FC10-Zygoascus hellenicus, R2-Rhodotorula mucilaginosa, YMA1-Saccharomyces cerevisiae

decrease in lipid content as the fermentation time increased from 24 to $120 \mathrm{~h}$. The low lipid output at later stages of growth despite nitrogen limitation was attributed to the metabolic shift towards synthesis of endopolysaccharides.

For both strains FK09 and R2, the growth of yeast strains were accompanied by the production of organic acids that led to significant lowering of $\mathrm{pH}$ at all stages of growth. The synthesis of microbial lipids and/or polysaccharides with secretion of low-molecular weight metabolites like polyols (mannitol) or citric acid by most of the genera including Cryptococcus, Yarrowia, and Rhodotorula under nitrogen-limiting conditions using glucose or glycerol as a sole carbon source has been reported by Athenaki et al. (2018) and Filippousi et al. (2019). The glucose consumption in case of both the strains R2 and FK09 was faster during the early stages of growth until $96 \mathrm{~h}$ after which it became stabilized. This was followed by lipid accumulation phase in case of Rhodotorula mucilaginosa R2. Similar results were obtained by Vyas and Chhabra (2019) using oleaginous yeast Cystobasidium oligophagum JRC1. The glucose assimilation capacity of $R$. mucilaginosa $\mathrm{R} 2$ was low $(9.18 \mathrm{~g} / \mathrm{L})$ as compared to $W$. anomalus FK09 (23.29 g/L) possibly due to low pH of the culture media that limited the utilization of glucose from the media by Rhodotorula mucilaginosa R2, whereas Wickerhamomyces anomalus FK09 continued to assimilate glucose at lower $\mathrm{pH}$. In $R$. mucilaginosa $\mathrm{R} 2$, the lipid accumulation phase started after $72 \mathrm{~h}$ with maximum production (lipid content of $21.89 \%$ ) at $120 \mathrm{~h}$ of incubation.
Subsequently, the lipid accumulation in five of the selected yeast strains (on the basis of high biomass concentration and/or high lipid content in lipid production medium) was evaluated by Nile red staining, fluorescence microscopy, and spectrometry techniques.

\section{Detection of LBs by Nile red staining and fluorescence microscopy}

Nile red staining was performed in selected yeast isolates representing five different genera. Yeast strains belonging to the genera Rhodotorula, Wickerhamomyces, Zygoascus, Pichia, and Saturnispora contained lipid bodies (present as yellow-gold emissions). The shape, number, and localization of lipid bodies were found to vary among the yeast isolates belonging to different genera. Cells of R.mucilaginosa R2, W. anomalus FK09, Z. hellenicus FC10, S. diversa FO05, and P. Krudivazevi FK03 produced around 2-3 lipid bodies within the cytoplasm. In contrast, cells of Saccharomyces cerevisiae YMA1 did not contain any neutral lipid bodies (indicated by an absence of yellow-gold emission). As shown in Fig. 6, fluorescence emission observed was comparable to several oleaginous yeasts and fungi as reported by other studies (Viñarta et al. 2016; Bardhan et al. 2019b. Hydrophobicity of the lipid affects its fluorescence emission (Poontawee et al. 2017). Neutral lipids fluoresce yellowgold whereas a red emission is observed with polar lipids in the presence of Nile red (Kimura et al. 2004). 


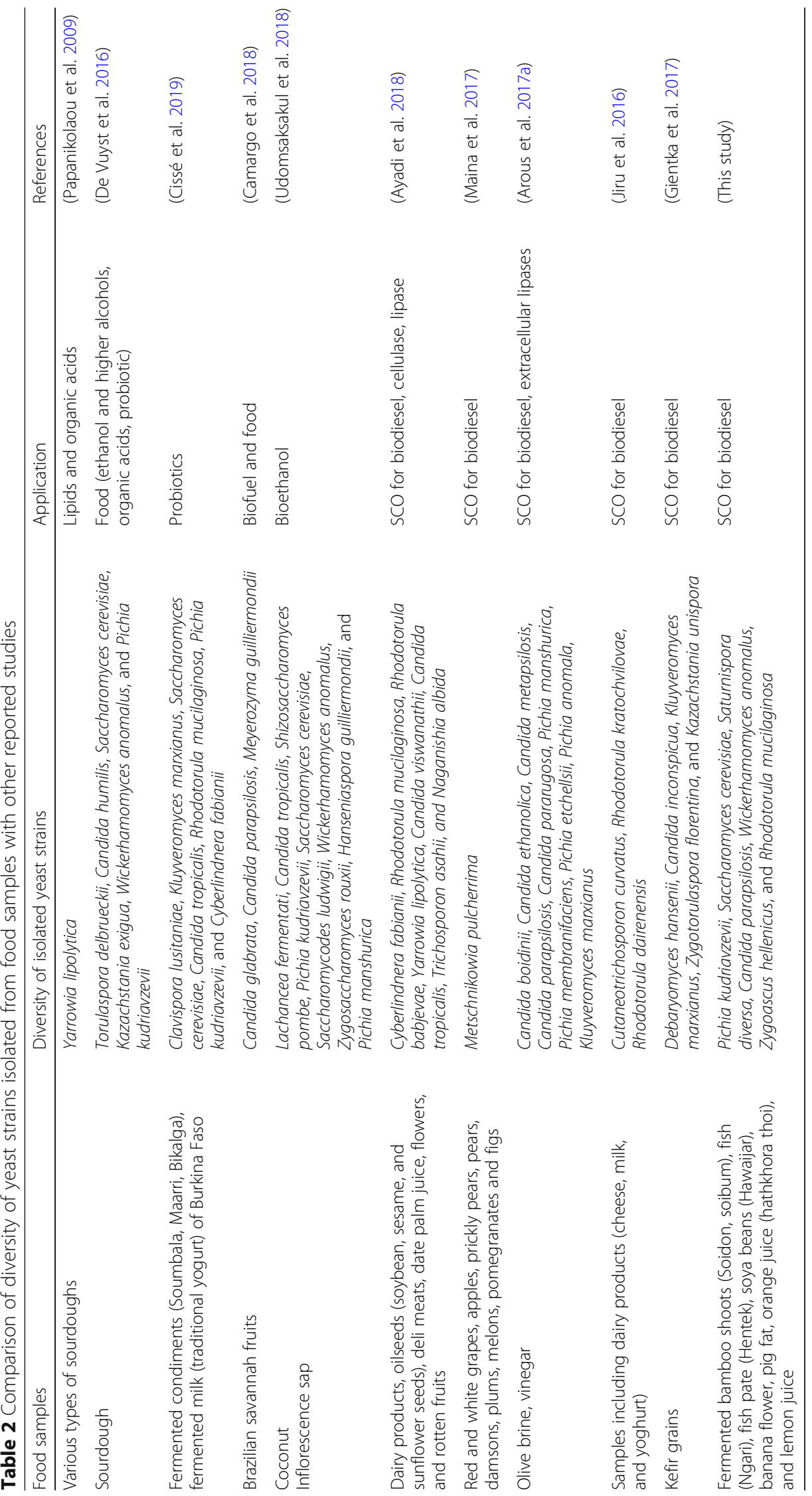


Table 3 Biomass concentrations ( $\mathrm{g} / \mathrm{L}$ ), lipid concentration $(\mathrm{g} / \mathrm{L})$, and lipid content (\%) after $96 \mathrm{~h}$ of growth; strains were grown in shake flasks containing $100 \mathrm{ml}$ of lipid production medium at $28{ }^{\circ} \mathrm{C}$

\begin{tabular}{|c|c|c|c|}
\hline Isolate & Total dry weight (g/L) & Lipid concentration (g/L) & Lipid content $(\% \mathrm{w} / \mathrm{w})$ \\
\hline S. diversa FO05 & $2.09 \pm 0.05^{a}$ & $0.39 \pm 0.006^{\mathrm{de}}$ & $18.6 \pm 0.65^{h}$ \\
\hline R. mucilaginosa R3 & $2.40 \pm 0.003^{b}$ & $0.34 \pm 0.003^{c}$ & $14.36 \pm 0.10^{\text {ef }}$ \\
\hline P. kudriavzevii FKO3 & $2.50 \pm 0.004^{c}$ & $0.27 \pm 0.003^{b}$ & $11.02 \pm 0.12^{c}$ \\
\hline Z. hellenicus FC10 & $2.57 \pm 0.043^{c}$ & $0.41 \pm 0.005^{\mathrm{ef}}$ & $16.32 \pm 0.10^{9}$ \\
\hline R. mucilaginosa R2 & $2.70 \pm 0.006^{d}$ & $0.58 \pm 0.003^{h}$ & $21.63 \pm 0.16^{i}$ \\
\hline R. mucilaginosa R1 & $2.78 \pm 0.042^{\text {de }}$ & $0.37 \pm 0.037^{c d}$ & $13.53 \pm 1.35^{\text {de }}$ \\
\hline S. cerevisiae NC3 & $2.85 \pm 0.028^{e}$ & $0.37 \pm 0.004^{c d}$ & $12.98 \pm 0.07^{d}$ \\
\hline S. cerevisiae YMA1 & $2.86 \pm 0.026^{e}$ & $0.27 \pm 0.003^{b}$ & $9.48 \pm 0.04^{b}$ \\
\hline R.mucilaginosa R4 & $2.87 \pm 0.042^{e}$ & $0.44 \pm 0.004^{f}$ & $15.60 \pm 0.07^{\mathrm{fg}}$ \\
\hline R. mucilaginosa R5 & $3.09 \pm 0.044^{f}$ & $0.20 \pm 0.02^{0 a}$ & $6.63 \pm 0.69^{a}$ \\
\hline R. mucilaginosa FK01 & $3.11 \pm 0.049^{f}$ & $0.17 \pm 0.004^{a}$ & $5.737 \pm 0.06^{\mathrm{a}}$ \\
\hline C. parapsilosis FK04 & $3.11 \pm 0.005^{f}$ & $0.35 \pm 0.003^{c d}$ & $11.34 \pm 0.09^{c}$ \\
\hline P. kudriavzevii FKO2 & $4.71 \pm 0.038^{9}$ & $0.27 \pm 0.003^{b}$ & $5.84 \pm 0.05^{\mathrm{a}}$ \\
\hline W. anomalus FKO9 & $5.66 \pm 0.033^{h}$ & $0.51 \pm 0.007^{9}$ & $9.13 \pm 0.07^{b}$ \\
\hline
\end{tabular}

Strains are arranged in increasing order of biomass concentrations. The data are given as averages of three replicates with standard error. Values followed by the different letters are significantly different at $p<0.05$

\section{Detection of the accumulated intracellular lipid by fluorescence spectrometry}

Intracellular lipids were detected by Nile red fluorescence spectrometry with excitation at $488 \mathrm{~nm}$. Excitation wavelength range of $480-490 \mathrm{~nm}$ is commonly used for the fluorescence measurements of intracellular neutral lipids (Kimura et al. 2004). Emission spectra with different fluorescence intensities were obtained with all the yeast isolates in either $565-585 \mathrm{~nm}$ or $600-605 \mathrm{~nm}$ range (Fig. 7). The peak of fluorescence intensity corresponds to the amount of accumulated intracellular lipids. The fluorescence intensity varied with different genera of yeast strains as reported by (Ramírez-Castrillón et al. 2017). Wickerhamomyces anomalus FK09 was found to accumulate the maximum intracellular neutral lipids. Several studies have reported the accumulation of intracellular lipid bodies by oleaginous yeast W. Anomalus (Arous et al. 2017b; Souza et al. 2017).

\section{Fatty acid composition}

The primary FAME constituents were evaluated by GCMS and identified from NIST11.L database. Fatty acid (FA) analysis in yeast is important both form biodiesel standpoint as well as to differentiate closely related yeast strains at generic and specific level (Phukan et al. 2019). FA profile of all the yeast isolates predominantly contained palmitic acid (C16:0) 19.24-30.76\%, stearic acid (C18:0) 3.13-12.69\%, oleic acid (C18:1) 40.45-62.7\%,

Table 4 Comparison of lipid production parameters with other reported oleaginous yeasts

\begin{tabular}{|c|c|c|c|c|c|}
\hline Yeast strain & Feedstock & $\begin{array}{l}\text { Incubation } \\
\text { time }(\mathrm{h})\end{array}$ & $\begin{array}{l}\text { Stress (nutrient } \\
\text { limitation) }\end{array}$ & $\begin{array}{l}\text { Lipid conc. }(\mathrm{g} / \mathrm{L}) \text {, } \\
\text { lipid content }(\%)\end{array}$ & Reference \\
\hline Rhodotorula mucilaginosa IIPL32 & $\begin{array}{l}\text { Sugarcane bagasse } \\
\text { (xylose) }\end{array}$ & 56 & Nitrogen & $\begin{array}{l}0.17 \mathrm{~g} / \mathrm{g}, 15.6 \mathrm{~g} / \mathrm{L} \\
\text { (biomass conc.) }\end{array}$ & (Khot and Ghosh 2017) \\
\hline $\begin{array}{l}\text { Wickerhamomyces anomalus } \\
\text { strain EC28 }\end{array}$ & $\begin{array}{l}\text { Deproteinized cheese } \\
\text { whey }\end{array}$ & 96 & Nitrogen & $0.65 \pm 0.01,24.00 \pm 0.24$ & (Arous et al. 2017b) \\
\hline Debaryomyces etchellsii & $\begin{array}{l}\text { Deproteinized cheese } \\
\text { whey }\end{array}$ & 96 & Nitrogen & $0.4 \pm 0.05,15.9 \pm 0.93$ & (Arous et al. 2016) \\
\hline Meyerozyma guilliermondii BI281A & Pure glycerol & 120 & - & $108 \mathrm{mg} / \mathrm{L}, 34.97$ & (Ramírez-Castrillón et al. 2017) \\
\hline Cystobasidium oligophagum JRC1 & $\begin{array}{l}\text { Untreated cheese } \\
\text { whey }(100 \%)\end{array}$ & 168 & - & $4.57 \pm 0.13,21.79 \pm 1.00$ & (Vyas and Chhabra 2019) \\
\hline Rhodotorula mucilaginosa R2 & Glucose & 96 & Nitrogen & $0.58 \pm 0.009,21.63 \pm 1.2$ & (This study) \\
\hline Wickerhamomyces anomalus FK09 & Glucose & 96 & Nitrogen & $0.51 \pm 0.007,9.13 \pm 0.2$ & (This study) \\
\hline Zygoascus hellenicus FC10 & Glucose & 96 & Nitrogen & $0.41 \pm 0.004,16.3 \pm 0.4$ & (This study) \\
\hline Saturnispora diversa FO05 & Glucose & 96 & Nitrogen & $0.39 \pm 0.008,18.57 \pm 0.7$ & (This study) \\
\hline
\end{tabular}



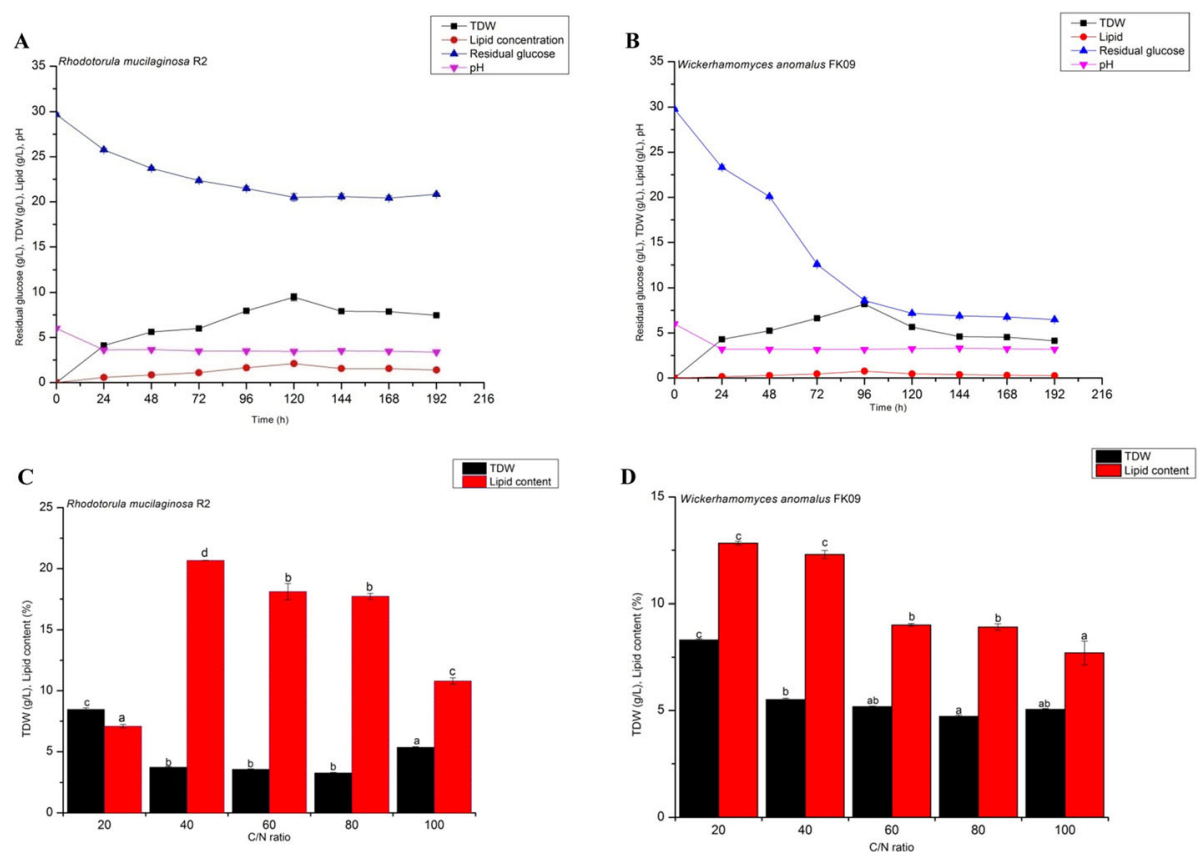

Fig. 5 Full growth kinetics depicting the glucose consumption (g/L), total dry weight (g/L), and lipid concentration ( $\mathrm{g} / \mathrm{L}$ ) for a Rhodotorula mucilaginosa R2 and $\mathbf{b}$ Wickerhamomyces anomalus FK09. Optimization of C/N ratio for $\mathbf{c}$ Rhodotorula mucilaginosa R2 and $\mathbf{d}$ Wickerhamomyces anomalus FKO9
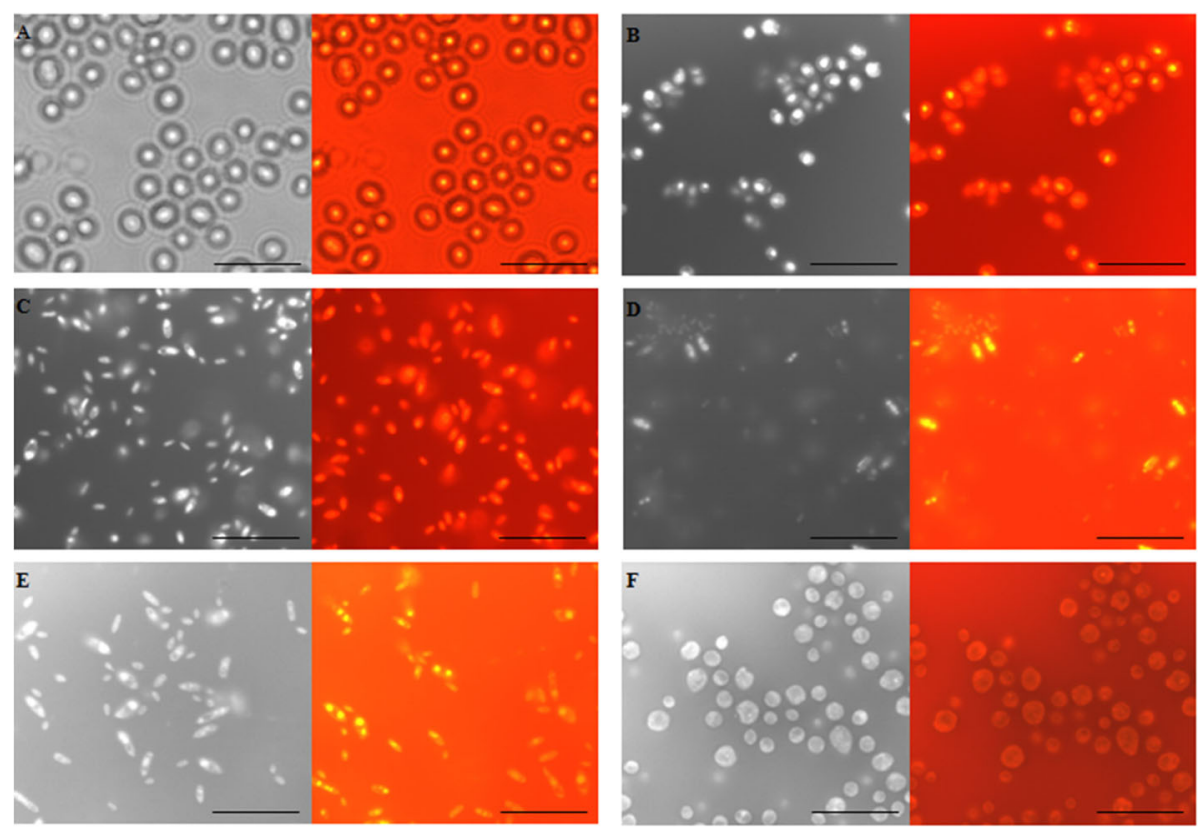

Fig. 6 Fluorescence micrographs of Nile red stained lipid bodies from yeasts: a $R$. mucilaginosa isolate R2, b Wickerhamomyces anomalus isolate FK09, c Saturnispora diversa isolate FO05, b Pichia krudiavzevii isolate FK03, e Zygoascus hellenicus isolate FC10, and f Saccharomyces cerevisiae isolate YMA1 after $96 \mathrm{~h}$ of culture in lipid production medium. Photomicrographs were taken under $\times 100$ oil immersion objective, bar indicates $2 \mu \mathrm{M}$ 


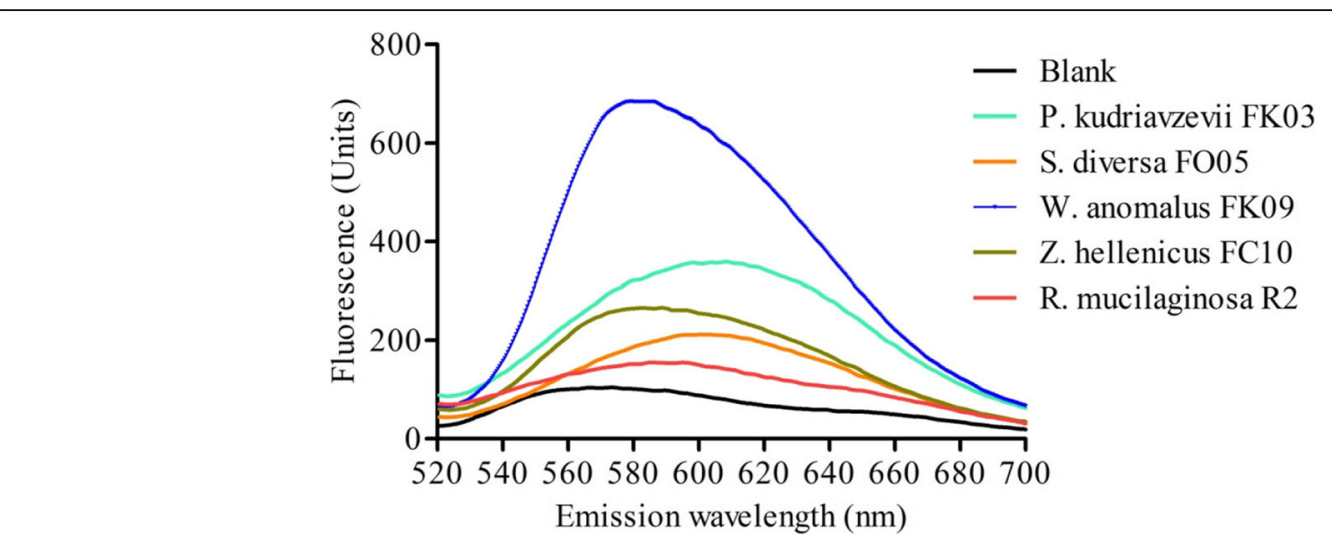

Fig. 7 Emission spectra of different yeast cell suspension with Nile red $(0.1 \mathrm{mg} / \mathrm{ml}$ in DMSO)

and linoleic acid (C18:2) 11.45-31.09\%. Whereas medium chain (e.g., C12 and C14) or long-chain (e.g., C18:3, C20 and C22) FAs were produced in negligible quantities ( $\leq 1 \% \mathrm{w} / \mathrm{w}$ of total FAs). As predicted, in yeast oil, the presence of intracellular stored lipids (stearic and oleic acids) is higher as compared to membrane lipids (linoleic acid) (Thiru et al. 2011). Figure 8 depicts the GC-MS chromatogram of the standard FAME mix and FAME derived from representative yeast strain $R$. mucilaginosa $\mathrm{R} 2$. The relative abundance of FA in the yeast isolates, representing each of the seven different genera, is shown in (Table 5). Eighteen-carbon FA was the most abundant $(56.72-78.63 \%)$ in all the yeast isolates. Our results are comparable to FA composition of lipids produced by Cryptococcus podzolicus, Trichosporon porosum, Pichia segobiensis, Cryptococcus vishniaccii, and Rhodosporidium fluvial, as reported by other authors (Schulze et al. 2014; Deeba et al. 2016;

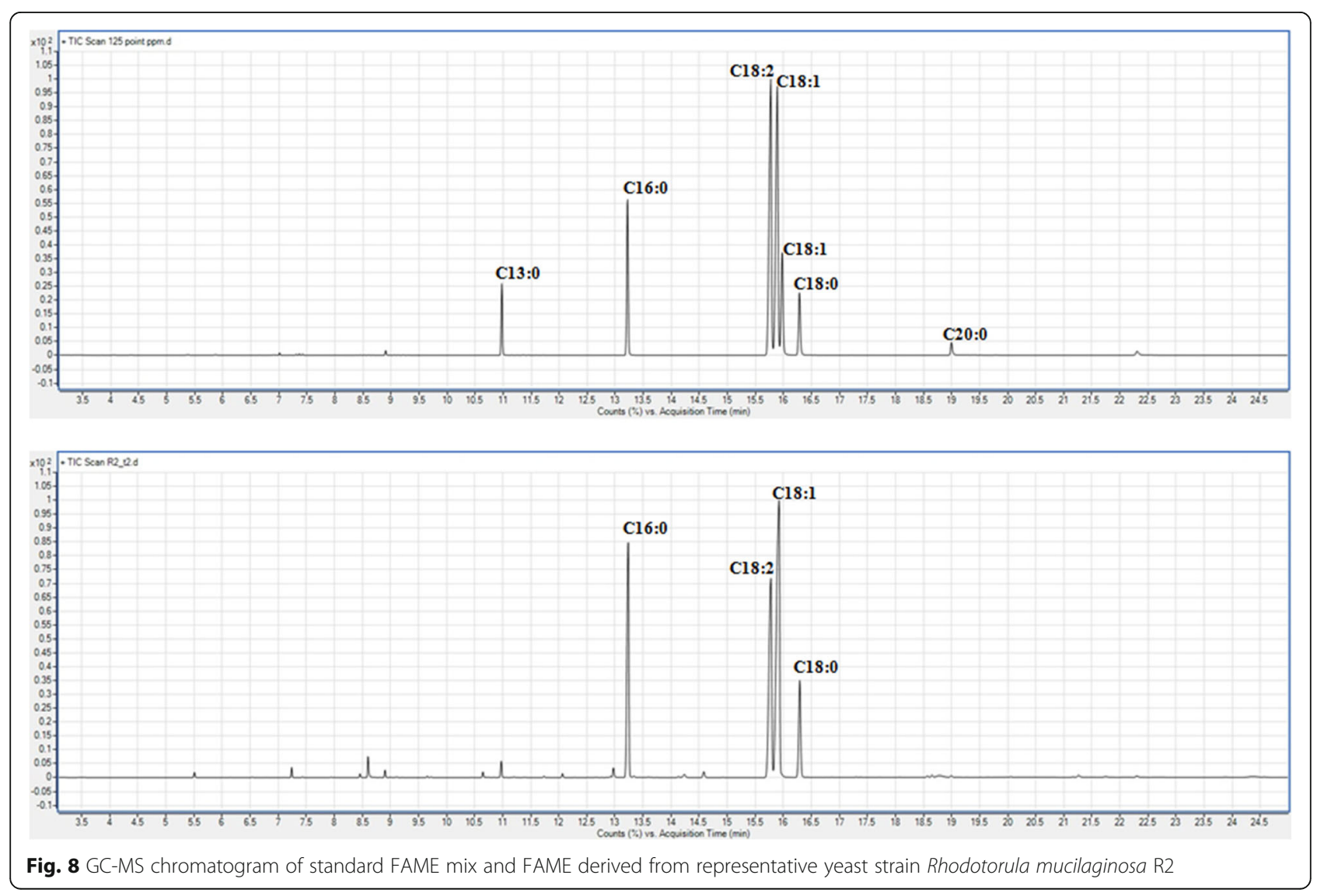


Table 5 The total percentage of fatty acid methyl esters (FAMEs) produced by different yeast strains when grown on lipid production medium at $28{ }^{\circ} \mathrm{C}, 140 \mathrm{rpm}$ for $96 \mathrm{~h}$ and its comparison with plant-based oils

\begin{tabular}{|c|c|c|c|c|}
\hline \multirow[b]{2}{*}{ Yeast Strain } & \multicolumn{4}{|c|}{ Relative abundance of FA (w/w \%) } \\
\hline & C16:0 (palmitic acid) & C18:0 (stearic acid) & C18:1 (oleic acid) & C18:2 (linoleic acid) \\
\hline Rhodotorula mucilaginosa isolate R2 & $20.89 \pm 1.05$ & $9.9 \pm 1.37$ & $40.45 \pm 3.48$ & $28.75 \pm 3.17$ \\
\hline Pichia kudriavzevii isolate FKO2 & $19.86 \pm 0.6$ & $3.13 \pm 0.065$ & $49.42 \pm 0.63$ & $27.58 \pm 0.07$ \\
\hline Candida parapsilosis isolate FKO4 & $20.13 \pm 0.8$ & $5.7 \pm 0.14$ & $62.7 \pm 0.36$ & $11.45 \pm 0.6$ \\
\hline Saturnispora diversa isolate FO05 & $19.24 \pm 1.1$ & $6 \pm 0.18$ & $56.58 \pm 1.01$ & $18.16 \pm 1.93$ \\
\hline Wickerhamomyces anomalus isolate FKO9 & $19.59 \pm 0.3$ & $3.41 \pm 0.14$ & $45.88 \pm 0.17$ & $31.09 \pm 0.69$ \\
\hline Zygoascus hellenicus isolate FC10 & $19.51 \pm 1.3$ & $9.3 \pm 0.84$ & $51.23 \pm 5.4$ & $19.89 \pm 1.8$ \\
\hline Saccharomyces cerevisiae YMA1 & 30.57 & 12.69 & 56.72 & Not detected \\
\hline \multicolumn{5}{|l|}{ Plant-based oils } \\
\hline Palm oil & $32-46.3$ & $4-6.3$ & $37-53$ & $6-12$ \\
\hline Soya bean oil & 11 & 4 & 23.4 & 53.2 \\
\hline Jatropha oil & 14.66 & 6.86 & 39.08 & 32.48 \\
\hline
\end{tabular}

Poontawee et al. 2016). The FA compositional profiles of the yeast strains were found to be comparable with vegetable oil such as rapeseed oil, palm oil, soya bean oil, and Jatropha oil which are conventionally used for biodiesel production (Vyas and Chhabra 2017). In our study, the concentration of mono-unsaturated FA (C18: 1 ) was found to be in the range of $(40.45-62.7 \%)$ for all the tested yeast strains and proportionately higher (i.e., $\geq$ $50 \%$ w/w of total FAs) in case of Candida parapsilosis FK04, Saturnispora diversa FO05, Zygoascus hellenicus FC10, and Saccharomyces cerevisiae YMA1 representing similarity in FA composition to rapeseed oil which is considered as the model oil for biodiesel synthesis (Papanikolaou et al. 2017). Lipids having FA composition with high amount of saturated FA $(\geq 30 \%$ w/w of total FAs) were found in case of Rhodotorula mucilaginosa R2, Zygoascus hellenicus FC10, and Saccharomyces cerevisiae YMA1 representing similarity with animal fats and palm oil (Maina et al. 2018). Moreover, it was observed for all strains tested presented elevated quantities of linoleic acid ( $\geq 15 \% \mathrm{w} / \mathrm{w}$ of total FAs) with the highest content of polyunsaturated FA (C18:2) in case of $W$. anomalus FK09 (31.09 \pm 0.69\%), whereas C. parapsilosis FK04 has the lowest concentration of C18:2 (11.45\%) and in S. cerevisiae YMA1, this acid was negligible. Similar findings were obtained with $C$. pararugosa strain BM24, C. metapsilosis strain EL2, and C. parapsilosis strain LV2, having high percentage of oleic acid and the low percentage of linoleic acid (Arous et al. 2017a).

\section{Conclusion}

A total of 14 yeast isolates belonging to seven different genera were established as pure culture from the traditional fermented food and beverages of Manipur and Mizoram, India. Molecular identification of all the yeast isolates was performed by PCR amplification of 5.8S-ITS and D1/D2 domain of the 26S rRNA gene of the isolates. The total lipid content of all the obtained yeast isolates varied between $5.7 \pm 0.1$ and $21.63 \pm 1.2 \%$. Rhodotorula mucilaginosa R2 gave the highest lipid content (21.63 \pm $\left.1.2^{\mathrm{i}} \%\right)$. The lipid content in two of the most promising strains $R$. mucilaginosa R2 and $W$. anomalus FK09 (selected on the basis of highest lipid content and biomass) increased to $22.21 \pm 0.4 \%$ and $12.83 \pm 0.08 \%$ using $\mathrm{C} / \mathrm{N}$ 40 and 20 respectively. The ability of the some of the yeast strains to grow well and accumulate non-negligible quantities of intracellular lipid droplets having similar fatty acid composition to that of vegetable oil suggests their suitability for further studies. Particularly, the pink yeast $R$. mucilaginosa $\mathrm{R} 2$ may provide an alternative platform for SCO production and therefore this organism should be studied in detail. The production of metabolic co-products like carotenoids, endopolysaccharides, polyols, and organic acids by most yeast isolates are valuable renewable resources as commodity chemicals.

\section{Acknowledgements}

The author MM thanks Tezpur University for providing various research facilities.

\section{Authors' contributions}

$\mathrm{PB}, \mathrm{KG}$ and $\mathrm{MM}$ conceived the project and designed the experiments; $\mathrm{PB}$ performed the experiments; Analyzed and interpreted the data; Wrote the paper. SK and PC performed the GC-MS analysis. CC and EK performed fluorescence microscopy imaging and analysis. WG, KG and MM read and revised the manuscript. All the authors read and approved the final manuscript.

\section{Funding}

The authors acknowledge the Department of Biotechnology (DBT), Government of India, for providing financial support through NECBH Twinning 2018 (Grant No. NECBH/2019-20/197). The author PB expresses gratitude to DBT for providing fellowship through DBT-JRF (DBT/JRF/BET-16/ 1/20 16/AL/110-501 dated June 29, 2016).

Ethics approval and consent to participate N/A. 


\section{Competing interests}

The authors declare that they have no conflict of interest.

\section{Author details}

'Department of Molecular Biology and Biotechnology, Tezpur University, Tezpur, Assam 784028, India. ${ }^{2}$ Division of Pharmaceutical Technology, Defence Research Laboratory, Tezpur, Assam 784001, India. ${ }^{3}$ Department of Chemical Engineering, Indian Institute of Technology, Guwahati, Assam 781039, India.

Received: 6 December 2019 Accepted: 26 March 2020

Published online: 14 May 2020

\section{References}

Abghari A, Chen S (2014) Yarrowia lipolytica as an oleaginous cell factory platform for production of fatty acid-based biofuel and bioproducts. Front Energy Res 2:21

Arous F, Atitallah I B, Nasri M, Mechichi T A (2017b) sustainable use of low-cost raw substrates for biodiesel production by the oleaginous yeast Wickerhamomyces anomalus. 3 Biotech 7:268

Arous F, Azabou S, Triantaphyllidou IE, Aggelis G, Jaouani A, Nasri M, Mechichi T (2017a) Newly isolated yeasts from Tunisian microhabitats: lipid accumulation and fatty acid composition. Eng. Life Sci 17:226-236

Arous F, Frikha F, Triantaphyllidou IE, Aggelis G, Nasri M, Mechichi T (2016) Potential utilization of agro-industrial wastewaters for lipid production by the oleaginous yeast Debaryomyces etchellsii. J Clean Prod 133:899-909

Athenaki M, Gardeli C, Diamantopoulou P, Tchakouteu SS, Sarris D, Philippoussis A, Papanikolaou S (2018) Lipids from yeasts and fungi: physiology, production and analytical considerations. J Appl Microbiol 124;(2):336-367

Ayadi I, Belghith H, Gargouri A, Guerfali M (2018) Screening of new oleaginous yeasts for single cell oil production, hydrolytic potential exploitation and agro-industrial by-products valorization. Process Saf Environ 119:104-114

Bardhan P, Gohain M, Daimary N, Kishor S, Chattopadhyay P, Gupta K, Chaliha C, Kalita E, Deka D, Mandal M (2019b) Microbial lipids from cellulolytic oleaginous fungus Penicillium citrinum PKB20 as a potential feedstock for biodiesel production. Ann Microbiol:1-12

Bardhan P, Gupta K, Mandal M (2019a) Microbes as bio-resource for sustainable production of biofuels and other bioenergy products. In: New and future developments in microbial biotechnology and bioengineering, 1st edn Elsevier, pp 205-222

Bellou S, Baeshen MN, Elazzazy AM, Aggeli D, Sayegh F, Aggelis G (2014) Microalgal lipids biochemistry and biotechnological perspectives. Biotechnol Adv 32:1476-1493

Bellou S, Triantaphyllidou IE, Aggeli D, Elazzazy AM, Baeshen MN, Aggelis G (2016) Microbial oils as food additives: recent approaches for improving microbial oil production and its polyunsaturated fatty acid content. Curr Opin Biotech 37:24-35

Bligh EG, Dyer WJ (1959) A rapid method of lipid extraction and purification. Can J Biochem Physiol 37:911-917

Blomqvist J, Pickova J, Tilami SK, Sampels S, Mikkelsen N, Brandenburg J, Sandgren M, Passoth V (2018) Oleaginous yeast as a component in fish feed. Scientific Reports 8:15945

Camargo JZ, Nascimento VM, Stefanello I, de Andrade Silva CA, Gonçalves FA, Perdomo IC, Vilela DM, Simionatto S, Pereira RM, da Paz MF, RSR L (2018) Biochemical evaluation, molecular characterization and identification of novel yeast strains isolated from Brazilian savannah fruits, chicken litter and a sugar and alcohol mill with biotechnological potential for biofuel and food industries, Biocatal. Agric Biotechnol. 16:390-399

Cissé H, Kagambèga B, Sawadogo A, Tankoano A, Sangaré G, Traoré Y, Ouoba IIL, Savadogo A (2019) Molecular characterization of Bacillus, lactic acid bacteria and yeast as potential probiotic isolated from fermented food. Scientific African e00175

Das G, Patra JK, Singdevsachan SK, Gouda S, Shin HS (2016) Diversity of traditional and fermented foods of the Seven Sister states of India and their nutritional and nutraceutical potential: a review. Front Life Sci 9:292-312

De Deken RH (1966) The Crabtree effect: a regulatory system in yeast. Microbiology 44:149-156

De Vuyst L, Harth H, Van Kerrebroeck S, Leroy F (2016) Yeast diversity of sourdoughs and associated metabolic properties and functionalities. Int Food Microbiol 239:26-34
Deeba F, Pruthi V, Negi, Y.S (2017) Fostering triacylglycerol accumulation in novel oleaginous yeast Cryptococcus psychrotolerans IITRFD utilizing groundnut shell for improved biodiesel production, Bioresource Technol 242:113-120

Deeba F, Pruthi V, Negi YS (2016) Converting paper mill sludge into neutral lipids by oleaginous yeast Cryptococcus vishniaccii for biodiesel production. Bioresource Technol 213:96-102

Filippousi R, Antoniou D, Tryfinopoulou P, Nisiotou AA, Nychas GJ, Koutinas AA, Papanikolaou S (2019) Isolation, identification and screening of yeasts towards their ability to assimilate biodiesel-derived crude glycerol: microbial production of polyols, endopolysaccharides and lipid. J Appl Microbiol 127: $1080-1100$

Gientka I, Kieliszek M, Jermacz K, Błażejak S (2017) Identification and characterization of oleaginous yeast isolated from kefir and its ability to accumulate intracellular fats in deproteinated potato wastewater with different carbon sources, Biomed Res Int

Jaiboon K, Lertwattanasakul N, Limtong P, Limtong S (2016) Yeasts from peat in a tropical peat swamp forest in Thailand and their ability to produce ethanol, indole-3-acetic acid and extracellular enzymes. Mycol Prog 15:755-770

Jiru TM, Abate D, Kiggundu N, Pohl C, Groenewald M (2016) Oleaginous yeasts from Ethiopia. AMB Express 6:78

Khot M, Ghosh D (2017) Lipids of Rhodotorula mucilaginosa IIPL32 with biodiese potential: Oil yield, fatty acid profile, fuel properties. J Basic Microbiol 57;(4):345-352

Kimura K, Yamaoka M, Kamisaka Y (2004) Rapid estimation of lipids in oleaginous fungi and yeasts using Nile red fluorescence. J Microbiol Methods 56:331-338

Kodama S, Nakanishi H, Thalagala TATP, Isono N, Hisamatsu M (2013) A wild and tolerant yeast suitable for ethanol fermentation from lignocellulose. J Biosci Bioeng 115:557-561

Kolouchová I, Matátková O, Sigler K, Masák J, Řezanka T (2016) Production of palmitoleic and linoleic acid in oleaginous and nonoleaginous yeast biomass. Int J Anal Chem.

Kot AM, Błażejak S, Kurcz A, Gientka I, Kieliszek M (2016) Rhodotorula glutinis - potential source of lipids, carotenoids, and enzymes for use in industries. Appl Microbiol Biotechnol 100:6103-6117

Kurtzman CP (2015) Description of Martiniozyma gen. nov. and transfer of seven Candida species to Saturnispora as new combinations. Antonie Van Leeuwenhoek 108:803-809

Lamers D, van Biezen N, Martens D, Peters L, van de Zilver E, Jacobs-van Dreumel N, Wijfels RH, Lokman C (2016) Selection of oleaginous yeasts for fatty acid production. BMC Biotechnol 16:45

Ma Y, Gao Z, Wang Q, Liu Y (2018) Biodiesels from microbial oils: opportunity and challenges. Bioresource Technol 263:631-641

Maina S, Pateraki C, Kopsahelis N, Paramithiotis S, Drosinos EH, Papanikolaou S, Koutinas A (2017) Microbial oil production from various carbon sources by newly isolated oleaginous yeasts. Eng. Life Sci 17:333-344

Manhar AK, Saikia D, Bashir Y, Mech RK, Nath D, Konwar BK, Mandal M (2015) In vitro evaluation of celluloytic Bacillus amyloliquefaciensAMS1 isolated from traditional fermented soybean (Churpi) as an animal probiotic. Res Vet Sci 99: 149-156

Miller GL (1959) Use of dinitrosalicylic acid reagent for determi- nation of reducing sugar. Anal Chem 31:426-428

Morrison WR, Smith LM (1964) Preparation of fatty acid methyl esters and dimethylacetals from lipids with boron fluoride-methanol. J Lipid Res 5:600-608

Papanikolaou S, Aggelis G (2019) Sources of microbial oils with emphasis to Mortierella (Umbelopsis) isabellina fungus. World J Microb Biot 35:63

Papanikolaou S, Chatzifragkou A, Fakas S, Galiotou-Panayotou M, Komaitis M, Nicaud JM, Aggelis G (2009) Biosynthesis of lipids and organic acids by Yarrowia lipolytica strains cultivated on glucose. Eur J Lipid Sci Tech 111(12): $1221-1232$

Papanikolaou S, Kampisopoulou E, Blanchard F, Rondags E, Gardeli C, Koutinas AA, Chevalot I, Aggelis G (2017) Production of secondary metabolites through glycerol fermentation under carbon-excess conditions by the yeasts Yarrowia lipolytica and Rhodosporidium toruloides. Eur J Lipid Sci Tech 119:1600507

Parsons S, Allen MJ, Chuck CJ (2020) Coproducts of algae and yeast-derived single cell oils: a critical review of their role in improving biorefinery sustainability. Bioresource Technol:122862

Patel A, Pruthi V, Pruthi PA (2019) Innovative screening approach for the identification of triacylglycerol accumulating oleaginous strains. Renew Energ 135:936-944

Phukan MM, Bora P, Gogoi K, Konwar BK (2019) Biodiesel from Saccharomyces cerevisiae: fuel property analysis and comparative economics. SN Applied Sciences 1:153 
Poontawee R, Yongmanitchai W, Limtong S (2017) Efficient oleaginous yeasts for lipid production from lignocellulosic sugars and effects of lignocellulose degradation compounds on growth and lipid production. Process Biochem 53:44-60

Poontawee R, Yongmanitchai W, Limtong S (2018) Lipid production from a mixture of sugarcane top hydrolysate and biodiesel-derived crude glycerol by the oleaginous red yeast, Rhodosporidiobolus fluvialis. Process Biochem 66: 50-161

Ramírez-Castrillón M, Jaramillo-Garcia VP, Rosa PD, Landell MF, Vu D, Fabricio MF, Ayub MA, Robert V, Henriques JA, Valente P (2017) The oleaginous yeast Meyerozyma guilliermondii BI281A as a new potential biodiesel feedstock: selection and lipid production optimization. Front Microbiol 8:1776

Ratledge C, Wynn JP (2002) The biochemistry and molecular biology of lipid accumulation in oleaginous microorganisms. Adv Appl Microbiol 51:1-52

Saikia D, Manhar AK, Deka B, Roy R, Gupta K, Namsa ND, Chattopadhyay P, Doley R, Mandal M (2018) Hypocholesterolemic activity of indigenous probiotic isolate Saccharomyces cerevisiae ARDMC1 in a rat model. J Food Drug Anal 26:154-162

Schoch CL, Seifert KA, Huhndorf S, Robert V, Spouge JL, Levesque CA, Chen W, Fungal Barcoding Consortium (2012) Nuclear ribosomal internal transcribed spacer (ITS) region as a universal DNA barcode marker for Fungi. Proc. Natl. Acad. Sci. 109:6241-6246.

Schulze I, Hansen S, Großhans S, Rudszuck T, Ochsenreither K, Syldatk C, Neumann A (2014) Characterization of newly isolated oleaginous yeastsCryptococcus podzolicus, Trichosporon porosum and Pichia segobiensis. AMB Express 4:24

Sitepu IR, Garay LA, Sestric R, Levin D, Block DE, German JB, Boundy-Mills KL (2014) Oleaginous yeasts for biodiesel: current and future trends in biology and production. Biotechnol Adv 32:1336-1360

Souza KST, Ramos CL, Schwan RF, Dias DR (2017) Lipid production by yeasts grown on crude glycerol from biodiesel industry. Prep Biochem Biotech 47: 357-363.

Steen EJ, Kang Y, Bokinsky G, Hu Z, Schirmer A, McClure A, Del Cardayre SB, Keasling JD (2010) Microbial production of fatty-acid-derived fuels and chemicals from plant biomass. Nature 463:559-562

Tanimura A, Sugita T, Endoh R, Ohkuma M, Kishino S, Ogawa J, Shima J, Takashima M (2018) Lipid production via simultaneous conversion of glucose and xylose by a novel yeast, Cystobasidium iriomotense. Plos One 13: e0202164

Thiru M, Sankh S, Rangaswamy V (2011) Process for biodiesel production from Cryptococcus curvatus. Bioresource Technol 102:10436-10440

Udomsaksakul N, Kodama K, Tanasupawat S, Savarajara A (2018) Diversity of ethanol fermenting yeasts in coconut inflorescence sap and their application potential. Science Asia 44:371-381

Uprety BK, Dalli SS, Rakshit SK (2017) Bioconversion of crude glycerol to microbial lipid using a robust oleaginous yeast Rhodosporidium toruloides ATCC 10788 capable of growing in the presence of impurities. Energy Convers Manag 135:117-128

Viñarta SC, Angelicola MV, Barros JM, Fernández PM, Mac Cormak W, Aybar MJ, De Figueroa LI (2016) Oleaginous yeasts from Antarctica: screening and preliminary approach on lipid accumulation. J Basic Microbiol 56:1360-1368

Vyas S, Chhabra M (2017) Isolation, identification and characterization of Cystobasidium oligophagum JRC1: a cellulase and lipase producing oleaginous yeast. Bioresource Technol 223:250-258

Vyas S, Chhabra M (2019) Assessing oil accumulation in the oleaginous yeast Cystobasidium oligophagum JRC1 using dairy waste cheese whey as a substrate. 3. Biotech 9:173

White TJ, Bruns T, Lee SJWT, Taylor J (1990) Amplification and direct sequencing of fungal ribosomal RNA genes for phylogenetics. PCR protocols: a guide to methods and applications. 18:315-322

Zhang X, Shen H, Yang X, Wang Q, Yu X, Zhao ZK (2016) Microbial lipid production by oleaginous yeasts on Laminaria residue hydrolysates. RSC Adv 6:26752-26756

Zhou YJ, Buijs NA, Zhu Z, Qin J, Siewers V, Nielsen J (2016) Production of fatty acid-derived oleo chemicals and biofuels by synthetic yeast cell factories. Nat Commun 7:1-9

Zhu LY, Zong MH, Wu H (2008) Efficient lipid production with Trichosporon fermentans and its use for biodiesel preparation. Bioresource Technol 99: $7881-7885$

\section{Publisher's Note}

Springer Nature remains neutral with regard to jurisdictional claims in published maps and institutional affiliations.

\section{Ready to submit your research? Choose BMC and benefit from:}

- fast, convenient online submission

- thorough peer review by experienced researchers in your field

- rapid publication on acceptance

- support for research data, including large and complex data types

- gold Open Access which fosters wider collaboration and increased citations

- maximum visibility for your research: over $100 \mathrm{M}$ website views per year

At BMC, research is always in progress.

Learn more biomedcentral.com/submissions 